\title{
The Use of Ecopath Software to Model Trophic Interactions within the Zooplankton Community of Discovery Bay, Jamaica
}

\author{
Gale Persad and Mona Webber \\ Department of Life Sciences, University of the West Indies (Mona), Kingston 7, Jamaica, West Indies
}

\begin{abstract}
Ecopath with Ecosim 5.1 software was used to formulate a reasonable model of the trophic interactions within the zooplankton community in Discovery Bay, Jamaica W.I. The zooplankton were separated into functional groups and, for each functional group, the software required the input of at least four basic parameters as well as the diet composition for each consumer group. These parameters included: biomass; production/biomass ratio; consumption/biomass ratio and ecotrophic efficiency. The model generated indicated that, with respect to the zooplankton community, Discovery Bay is a developing ecosystem which would not be particularly resistant to perturbations. It would therefore be unable to easily recover from significant stresses (eutrophication; increased fishing efforts etc.) imposed on the ecosystem, indicating the need for both short-term and long-term management strategies based on the level of use (or planned usage) of the bay.
\end{abstract}

\section{INTRODUCTION}

This study was originally designed as an element of a larger project which called for a comparison of the trophic functioning of Discovery Bay, Jamaica (a fished system) and the British Virgin Islands (a protected area). Ecopath software [1] was to be used in order to formulate working models of the trophic interactions in these two contrasting areas, which could then be used to formulate management strategies for their fisheries.

While several studies have been done on these individual ecosystems, few, if any, have attempted to link or compare the areas, in terms of energy flow (as is possible using Ecopath). Knowledge and understanding of the transfer of energy within pelagic ecosystems is essential for managing and maximising the fisheries generated in these areas. The economies of a large number of countries are dependent on, or partially dependent on, the fisheries of these countries. If any attempts are to be made to effectively manage these fisheries, the systems which support these fisheries must be understood.

The major gap in our knowledge which this study was designed to fill, was an understanding of the trophic interactions among the zooplankton groups in Discovery Bay. Zooplankton is the primary food source for the planktivorous fish groups in the area (including the Atherinidae, Clupidae, Engraulididae and the Hemiramphidae) and therefore an important aspect of the ecosystem under study. In order to investigate these relationships, Ecopath software and the data generated during a parallel study, were used to construct a massbalanced model of the Discovery Bay planktonic community. The Ecopath model, first developed by Polovina [2] and Polovina and Ow [1], was originally designed to

*Address correspondence to this author at the Department of Life Sciences, University of the West Indies (Mona), Kingston 7, Jamaica, West Indies; Tel: 876-927 1202; Fax: 876-977 1075;

E-mails: mona.webber@uwimona.edu.jm,galemford@yahoo.com estimate standing stock and production budget of a coral reef ecosytem in the Northwestern Hawaiian Islands. Ecopath II (versions released from 1990-1993) was further developed by Drs. Villy Christensen and Daniel Pauly at the International Centre for Living Aquatic Resource Management (ICLARM). They combined the original steady-state approach from Ecopath with techniques derived from network analysis and information theory. Ecopath II was designed as a tool to produce straightforward equilibrium box models for any kind of aquatic system [3].

Aquatic ecosystems are emphasized because the approach presented initially was applied to marine and freshwater systems and indeed, there have been a fair number of studies done in which Ecopath (I and II) software has been used to model trophic interactions in a variety of aquatic systems, (in both temperate and tropical latitudes). A few of these studies included the plankton as one or more of their input groups [4-10]. However, until this study, there seems to have been no study which has used this software exclusively to examine the trophodynamics of a planktonic ecosystem.

\section{SITE DESCRIPTION}

Discovery Bay is a relatively unspoilt bay, approximately $1.3 \mathrm{~km}$ wide, located on the north coast of Jamaica, (latitude $18^{0} 27.5^{\prime} \mathrm{N}-18^{0} 28.2^{\prime} \mathrm{N}$, longitude $77^{0} 25.1^{\prime} \mathrm{W}-77^{0} 24.0^{\prime} \mathrm{W}$ ) (see Fig. 1). The Discovery Bay Marine Laboratory is located on the western end of the bay. This portion of the bay is characterised by rocky shores with small mangrove stands. Depths in the shallow lagoon in front of the laboratory range from $1-5 \mathrm{~m}$. The seabed in this area is covered with seagrass beds, sand and small coral heads. There is also a submarine upwelling in this area almost directly in front of the laboratory's docks. Numerous other upwellings exist throughout the bay. Rocky shores are present from this western end of the bay through to the southern portions near Columbus Park (located adjacent to the Discovery Bay Marine laboratory). There are a number of seagrass beds in this area as well. Sandy shores stretch from the southern to eastern shores of the bay and are 


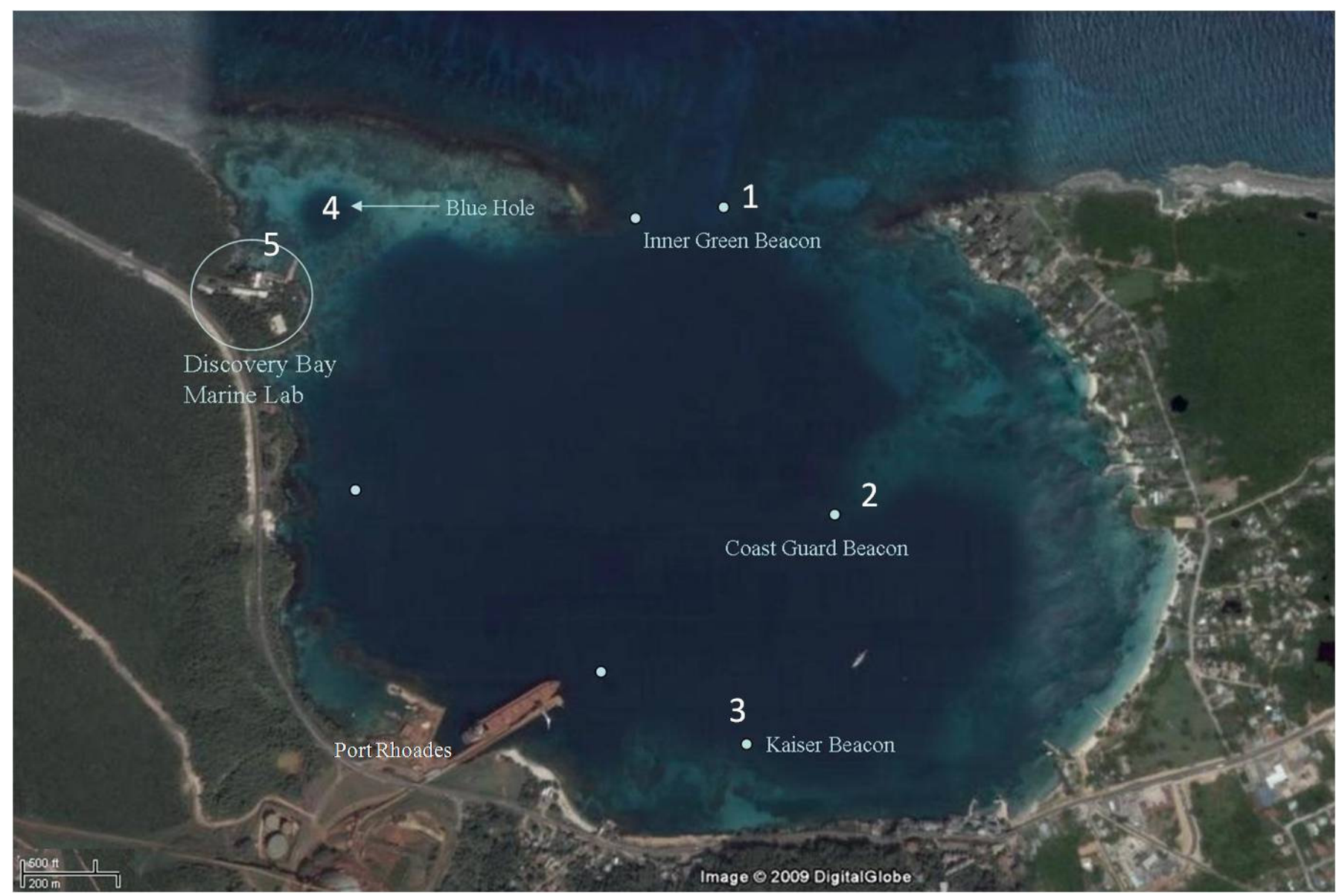

Fig. (1). General features of Discovery Bay, (Google Images, 2009) [12]. Stations occupied are numbered 1 to 5.

utilised by a number of concerns. There are two fishing beaches in this area as well as recreational beaches and private concerns. Remaining portions of the bay generally go from shallow depths through depths of approximately $30 \mathrm{~m}$ and deeper. The greatest depths of approximately $57 \mathrm{~m}$ are found near the centre of the bay. The sea bed in this area is characterised by soft mud.

The bay is connected to the open ocean via a relatively narrow opening (120 m wide) which is used as a ship channel. The outer limits of the bay are set by the west fore reef and back reef as well as the east fore reef. The ship channel runs in between the western and eastern reefs. The west fore reef is characterised by several species of coral including Acropora palmata, Montastrea annularis and Agaricia spp. [11].

The main industrial concern in the bay is the Kaiser Bauxite Company whose pier, Port Rhoades, is located in the south-western region of the bay.

\section{METHOD: DETERMINATION OF ZOOPLANKTON BIOMASS}

\section{Sampling Schedule}

Sampling for zooplankton was conducted monthly for thirteen months. Preliminary sampling began in December 1999. The final samples were collected in January 2001.
Plankton sampling was usually conducted over two days, depending on the weather.

\section{Zooplankton Collections}

At Stations 1 through 4 collections were obtained by replicate, vertical hauls employing plankton nets of four mesh sizes: $20 \mu \mathrm{m}, 64 \mu \mathrm{m}, 200 \mu \mathrm{m}$ and $600 \mu \mathrm{m}$. The $20 \mu \mathrm{m}$ net had a diameter of $0.25 \mathrm{~m}$. The $64 \mu \mathrm{m}$ and $200 \mu \mathrm{m}$ nets both had hoop diameters of $0.5 \mathrm{~m}$, while the $600 \mu \mathrm{m}$ net had

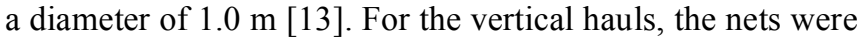
deployed with the aid of a manually operated winch mounted on one side of the boat. Weights were added to the cod ends of all the nets to ensure correct deployment.

The nets were hauled through $12 \mathrm{~m}, 15 \mathrm{~m}, 10 \mathrm{~m}$ and $15 \mathrm{~m}$ at stations 1 through 4 respectively. Two replicate hauls each were done with all the nets. The samples obtained with the $20 \mu \mathrm{m}$ net were immediately collected into $500 \mathrm{ml}$ plastic containers containing Bouin's solution. The samples obtained with the $64 \mu \mathrm{m}$ and $200 \mu \mathrm{m}$ nets were placed in (1 L) containers with $10 \mathrm{ml}$ (full strength) formalin. Collections made with the $600 \mu \mathrm{m}$ net were placed in containers free of formalin and processed for ctenophores on return to the laboratory.

At Station 5, two-minute horizontal tows were done with the $20 \mu \mathrm{m}, 64 \mu \mathrm{m}$ and $200 \mu \mathrm{m}$ nets. Replicate tows were 
done with each net and the volume filtered monitored with a flow-meter attached to each net.

\section{Laboratory Analyses: Identification, Enumeration and Biomass Determinations}

All the samples obtained from the $600 \mu \mathrm{m}$ hauls were processed for ctenophores immediately on returning to the laboratory. Ctenophores were identified, enumerated and measured. The size of a ctenophore was taken to be the length of the aboral axis of the animal, that is, the distance from the statocyst to the opening of the mouth.

All the samples were then transferred to $500 \mathrm{ml}$ plastic containers and preserved in $10 \%$ formalin for processing. The processing of the samples involved the determination of species composition, abundances and sizes. Most of the samples were sub-sampled using the Beaker Split Method [14]. Occasionally, due to the scarcity of animals, the complete sample was processed. All individuals were identified and enumerated using a Wild M7 stereomicroscope, with the aid of keys by Owre and Foyo [15] for the copepods and Mayer [16] for the medusae. Adults of each species were counted as separate categories. Copepodites and nauplii were not identified to species or stage and were therefore counted as two categories.

In order to prevent overestimation of the number of copepods in the population, each "category" was counted from only one mesh size. Samples collected with the $64 \mu \mathrm{m}$ mesh net were used for the identification and enumeration of copepodites and nauplii. Those collected from the $600 \mu \mathrm{m}$ mesh nets were processed for the carnivores (Chaetognatha, Cnidaria and Ctenophora) and the larger copepod species. The ciliates were only counted and identified from the $20 \mu \mathrm{m}$ collections and the remaining species were counted from the $200 \mu \mathrm{m}$ net collections.

The total volumes of water filtered by the plankton nets were used to determine the numbers $\mathrm{m}^{-3}$ at each station. Biomass estimations were then made by applying conversion factors (Table 1) to the abundance data. All of the conversion factors were generated from studies done in Jamaican waters.

Table 1. Conversion Factors Used for Biomass Estimates

\begin{tabular}{|l|c|c|}
\hline \multicolumn{1}{|c|}{ Group } & $\begin{array}{c}\text { Unit Biomass } \\
\left(\text { KJ/Individual/ } \mathbf{m}^{3}\right)\end{array}$ & Source \\
\hline \hline Calanoid Copepods $(200 \mu \mathrm{m})$ & $16.02 \times 10^{-5}$ & {$[17]$} \\
\hline Calanoid Copepods $(600 \mu \mathrm{m})$ & $49.7 \times 10^{-5}$ & {$[17]$} \\
\hline Cyclopoid Copepods & $3.672 \times 10^{-5}$ & {$[17]$} \\
\hline Harpacticoid Copepods & $1.212 \times 10^{-5}$ & {$[17]$} \\
\hline Nauplii & $0.155 \times 10^{-5}$ & {$[17]$} \\
\hline Copepodites & $0.801 \times 10^{-5}$ & {$[17]$} \\
\hline Carnivores: Ctenophores & 0.016 & {$[17]$} \\
\hline Carnivores: Medusae & 0.004 & {$[18]$} \\
\hline Carnivores: Chaetognaths & 0.006 & {$[19]$} \\
\hline Larvaceans (Oikopleura sp.) & 0.00002 & {$[19]$} \\
\hline Larvae & 0.0007 & {$[19]$} \\
\hline
\end{tabular}

\section{METHOD: APPLICATION OF THE ECOPATH SOFTWARE}

The planktonic community in Discovery Bay, Jamaica, was modeled using Ecopath with Ecosim 5.1 software which required the input of the following four basic parameters for each "functional group" as well as diet compositions for each consumer. It was also possible to enter only three out of following four basic parameters as well as diet compositions and allow Ecopath to estimate the missing parameters.

\section{Biomass in the Habitat Area (B) $\left(\mathrm{J} \mathrm{m}^{-2}\right)$}

This is defined as "the average biomass in the habitat area where the group occurs", assuming that an average value can be used to represent the biomass of each group [20]. Biomass estimates for the zooplankton groups were estimated for data collected during this investigation [21].

Biomass and production estimates for the phytoplankton were obtained from [13] and converted to the appropriate units by applying the conversion $1 \mathrm{mgC}$ phytoplankton = 11.40 calories [23]. An estimate for detritus biomass was made using the following empirical equation [24].

$\log D=0.954 \log P P+0.863 \log E-2.41$

where $\mathrm{D}$ is the detrital biomass

$\mathrm{PP}$ is the primary production $=2,458,056 \mathrm{mgC} \mathrm{m}^{-2} \mathrm{y}^{-1}$ [22]

$\mathrm{E}$ is the euphotic depth $=15 \mathrm{~m}$ [22].

Therefore, $\log \mathrm{D}=0.954 \log (2458056)+0.863 \log (15)-2.41$

$=6.097+1.015-2.41=4.70$

Therefore, $\mathrm{D}=$ Detrital Biomass $=50306.55 \mathrm{mgC} \mathrm{m}^{-2}$

$=136,976.86 \mathrm{~J} \mathrm{~m}^{-2}$

Ecopath can also automatically direct any production that is not consumed within the system to the detritus box.

\section{Production:Biomass Ratio (P/B) $\left(\mathrm{y}^{-1}\right)$}

Under most conditions in fisheries, the $\mathrm{P} / \mathrm{B}$ ratio is equal to the instantaneous rate of total mortality used by fisheries biologists [25]. That is, "production includes fishery yield plus predation plus net migration plus biomass change plus other mortality" [20].

However, this cannot be accurately applied to planktonic organisms.

Generally, Production is the product of Biomass and Growth. Therefore $\mathrm{P} / \mathrm{B}$ is a reflection of the growth rate of the group. $\mathrm{P} / \mathrm{B}$ 's were therefore estimated from data collected during this investigation as well as growth rates from the literature where thought to be underestimated by the present study (Table 1).

\section{Consumption:Biomass Ratio $(\mathrm{Q} / \mathrm{B})\left(\mathrm{y}^{-1}\right)$}

Consumption can be defined as "the intake of food by a group over the time period considered" (Christensen et al., 2005). Q/B (Consumption/Biomass) ratio was estimated from the input (modified) $\mathrm{P} / \mathrm{B}$ ratios and $\mathrm{P} / \mathrm{Q}$ ( = gross food conversion efficiency) ratios obtained from the literature using the relationship given in [20] (Table 2).

$Q / B=(P / B) /(P / Q)$ 
Table 2. Q/B Ratios for All Groups

\begin{tabular}{|c|c|c|c|}
\hline Group & $\mathbf{P} / \mathbf{B}^{\left(\mathbf{y}^{-1}\right)}$ & $\begin{array}{c}\mathbf{P} / \mathbf{Q} \text { (Gross Food } \\
\text { Conversion Efficiency) }\end{array}$ & $\mathbf{Q} / \mathbf{B}\left(\mathbf{y}^{\mathbf{- 1}}\right)$ \\
\hline \hline Carnivores & 0.100 & $0.3[26]$ & 0.333 \\
\hline Calanoids & 1.493 & $0.26[27]$ & 5.742 \\
\hline Cyclopoids & 0.657 & $0.26[27]$ & 2.527 \\
\hline Harpacticoids & 9.579 & $0.26[27]$ & 36.842 \\
\hline Larvaceans & 4.335 & $0.3[26]$ & 14.45 \\
\hline Copepodites & 0.69 & $0.3[26]$ & 2.3 \\
\hline Nauplii & 1.032 & $0.3[26]$ & 3.44 \\
\hline Larvae & 0.174 & $0.3[26]$ & 0.58 \\
\hline
\end{tabular}

\section{Ecotrophic Efficiency (EE) (Fraction of 1)}

The EE is the fraction of production that is used by the system (either passed up the food web, used for biomass accumulation, migration or export) [20]. An EE of 0.950 was used for all groups (see Table 3 for sources).

Table 3. References Used to Estimate Ecotrophic Efficiencies for Zooplankton and Phytoplankton

\begin{tabular}{|c|c|}
\hline Group & EE'S and References \\
\hline \hline & $0.95[28,29]$ \\
Zooplankton & 0.95 and $0.8[8]$ \\
& $0.50[30]$ \\
& $0.98[10]$ \\
\hline & $0.113[5]$ \\
Phytoplankton & $0.10[28]$ \\
& $0.50[29]$ \\
& $0.32[8,30]$ \\
& $0.53[6]$ \\
& $0.842[10]$ \\
\hline
\end{tabular}

\section{Diet Composition}

Diet composition must be entered in order for massbalance to be achieved. The diet composition of each group should sum to 1. Ecopath, is however capable of raising each diet composition to 1 if necessary. Diet compositions for the various groups were estimated by combining information on prey preferences from the appropriate literature (feeding studies and gut analyses) (Table 4) with background knowledge on the feeding habits and prey biomasses. The resultant diet input matrix is given in Table 5.

Table 4. Sources for Diet Composition Matrix

\begin{tabular}{|c|c|}
\hline Group & Source \\
\hline \hline Carnivores & {$[31-33]$} \\
\hline Calanoids & {$[34,35]$} \\
\hline Cyclopoids & {$[33,35,36]$} \\
\hline Harpacticoids & {$[34]$} \\
\hline Larvaceans & {$[34]$} \\
\hline Copepodites & {$[34]$} \\
\hline Nauplii & {$[34]$} \\
\hline Larvae & {$[37]$} \\
\hline
\end{tabular}

\section{METHOD: BALANCING THE MODEL}

When all necessary parameters and diet compositions were entered, the software solved a series of linear equations, one for each group in the system [20]. With sufficient information, Ecopath was capable of linking the production of each group with the consumption of all groups and used the linkages to estimate missing parameters and ensure mass balance between groups. This was done by considering the basic Ecopath "Master Equation 1":

Production $=$ Predation + Catches + Net migration + Accumulated biomass + Other mortality

After the missing parameters were estimated, energy balance within each group was ensured by considering "Master Equation 2":

Table 5. Input Diet Matrix (After $1^{\text {st }}$ Run)

\begin{tabular}{|l|c|c|c|c|c|c|c|c|}
\hline \multicolumn{1}{|c|}{ \# Prey/Predator } & $\mathbf{1}$ & $\mathbf{2}$ & $\mathbf{3}$ & $\mathbf{4}$ & $\mathbf{5}$ & $\mathbf{6}$ & $\mathbf{7}$ & $\mathbf{8}$ \\
\hline \hline 1. Carnivores & & & & & & & \\
\hline 2. Calanoids & 0.607 & & & & & & \\
\hline 3. Cyclopoids & 0.221 & & & & & & \\
\hline 4. Harpacticoids & 0.001 & & & & & & \\
\hline 5. Larvaceans & & & 0.125 & & & & \\
\hline 6. Copepodites & 0.071 & 0.480 & & & & & \\
\hline 7. Nauplii & & 0.264 & 0.500 & 0.500 & & 0.280 & & \\
\hline 8. Larvae & 0.100 & 0.500 & 0.020 & & & 0.001 & \\
\hline 9. Phytoplankton & & 0.186 & 0.250 & 0.500 & 1.00 & 0.719 & 0.800 & 0.200 \\
\hline 10. Detritus & & 0.020 & 0.125 & & & & \\
\hline \multicolumn{1}{|c|}{ TOTAL } & 1.00 & 1.00 & 1.00 & 1.00 & 1.00 & 1.00 & 1.00 & 1.00 \\
\hline
\end{tabular}




\section{Consumption $=$ Production + Respiration + Unassimilated Foods}

"The first Master Equation is crucial in linking the predator and prey in a system" [38]. Re-expressed and rearranged the equation reads,

$B_{i} \cdot(P / B)_{i} \cdot E_{i}=Y_{i}+\sum B_{j} \cdot(Q / B)_{j} \cdot D_{j i}+B A_{i}+N M_{i}$

where $B_{i}$ and $B_{j}$ are biomass levels (the latter pertaining to all consumers of $i) ; P / B_{i}$ is the production/biomass ratio; $E_{i}$ is the ecotrophic efficiency, or the production $(\mathrm{P}=\mathrm{B} *(\mathrm{P} / \mathrm{B}))$ that is utilized within the system (including net migration and biomass accumulation); $\mathrm{Y}_{\mathrm{i}}$ is equal the fisheries catch per unit area and time (i.e. $\mathrm{Y}=\mathrm{F}^{*} \mathrm{~B}$ ); $\mathrm{Q} / \mathrm{B}_{\mathrm{j}}$ is the food consumption per unit biomass of $\mathrm{j} ; \mathrm{DC}_{\mathrm{ji}}$ is the contribution of $\mathrm{i}$ to the diet of $\mathrm{j} ; \mathrm{BA}_{\mathrm{i}}$ is the biomass accumulation of $\mathrm{I}$ (positive or negative; flow rate with units of energy per unit area and time); $\mathrm{NM}_{\mathrm{i}}$ is the net migration of I (emigration less immigration) with unit of energy per unit area and time".

Table 6. Daily Specific Growth Rates $\left(G \mathrm{~d}^{-1}\right)$ Used for Revised Production Calculations. All Studies Conducted Off Kingston, Jamaica

\begin{tabular}{|c|c|}
\hline Plankton Group & G \\
\hline \hline Calanoids & $0.57[19]$ \\
\hline Cyclopoids & $0.58[19]$ \\
\hline Copepodites & $0.69[39]$ \\
\hline Nauplii & $0.91[39]$ \\
\hline
\end{tabular}

When inputs of the basic parameters and diet compositions were completed, a mass-balanced trophic model of the ecosystem was produced by balancing the model, that is, modifying the entries until input $=$ output for each box.

\section{Balancing the Model}

Despite the fact that the original inputs are chosen from the best available information, the model is unlikely to be balanced on the first run, i.e., not fulfilling realistic thermodynamic constraints [9]. Therefore, values of the parameters have to be modified until a balanced model is achieved, with the understanding that "the resulting model is one of the many possibilities that fit the defined constraints" [20].

After the original inputs were put into Ecopath's basic input sheet, as expected, mass-balance of the model could not be achieved mainly due to high EE's estimated by the software, for four of the groups (Table 6), indicating that demands on those groups were too high to be reasonable.

Table 7. Revised Inputs for Biomass and P/B Ratios for All Groups

\begin{tabular}{|c|c|c|}
\hline Plankton Group & AVG. Biomass J $\mathbf{~}^{-2}$ & P/B \\
\hline \hline Carnivores & 20859 & 0.100 \\
\hline Calanoids & 21940 & 1.493 \\
\hline Cyclopoids & 6910 & 0.657 \\
\hline Harpacticoids & 17 & 9.579 \\
\hline Larvaceans & 1036 & 4.335 \\
\hline Copepodites & Estimated by model & 0.69 \\
\hline Nauplii & Estimated by model & 1.032 \\
\hline Larvae & 51976 & 0.174 \\
\hline Phytoplankton & 37964.602 & 176.29 \\
\hline Detritus & 6.776 & N/A \\
\hline
\end{tabular}

Even with reasonable adjustments to the diet matrix, massbalance could not be reached mainly due to the low $\mathrm{P} / \mathrm{B}$ ratios calculated from the growth rates reported during this study, due to likely underestimation of these rates. That is, when the using the original $\mathrm{P} / \mathrm{B}$ ratios and a modified diet matrix, the EE's for the affected groups were still too high. Therefore growth rates (for affected groups) from comparable studies (usually done in Jamaican waters) (Table 6) were used in order to more reasonably estimate production and, subsequently, $\mathrm{P} / \mathrm{B}$. The model was also allowed to estimate the biomass for the "nauplii" and copepodites" (Table 7). Minor adjustments to the diet matrix

Table 8. Summary of Mass-Balance Solution. Values Highlighted in Red were Estimated by Ecopath

\begin{tabular}{|c|c|c|c|c|c|c|}
\hline Group Name & Trophic Level & $\mathrm{B}\left(\mathbf{J} / \mathbf{m}^{2}\right)$ & $\mathbf{P} / \mathbf{B}\left(\mathbf{y}^{-1}\right)$ & $\mathbf{Q} / \mathbf{B}\left(\mathbf{y}^{-1}\right)$ & $\mathbf{E E}$ & $\mathbf{P} / \mathbf{Q}$ \\
\hline Carnivores & 3.82 & 20859 & 0.1 & 0.333 & 0 & 0.3 \\
\hline Cyclopoids & 2.63 & 6910 & 0.657 & 2.527 & 0.338 & 0.26 \\
\hline Harpacticoids & 2.5 & 17 & 9.579 & 36.842 & 0.043 & 0.26 \\
\hline Copepodites & 2.28 & 120596.4 & 0.69 & 2.3 & 0.95 & 0.3 \\
\hline Nauplii & 2 & 122365 & 1.032 & 3.44 & 0.95 & 0.3 \\
\hline Larvae & 2.77 & 51976 & 0.174 & 0.58 & 0.804 & 0.3 \\
\hline Phytoplankton & 1 & 37964.6 & 176.29 & N/A & 0.087 & $\mathrm{~N} / \mathrm{A}$ \\
\hline
\end{tabular}


were also made (Table 5). These adjustments resulted in mass balance of the model.

\section{RESULTS}

\section{Mass-Balance Solution}

The mass-balance solution is presented in Table 8. The biomass of the copepodites and nauplii was estimated at 120596.4 and $122365.0 \mathrm{~J} \mathrm{~m}^{-2}$ respectively. Estimated ecotrophic efficiencies ranged from $0.015-0.804$ (Table 8).

\section{Transfer Efficiencies}

The transfer efficiencies between successive groups was calculated as "the ratio between the sum of exports from a given trophic level, plus the flow that is transferred from trophic level to the next, and the throughput on the trophic level" [20]. Transfer efficiencies (\%) by trophic levels are presented in Table 9.

Table 9. Transfer Efficiencies (\%) by Trophic Levels (TL)

\begin{tabular}{|c|c|c|c|c|c|}
\hline Source/TL & II & III & IV & V & VI \\
\hline \hline Producer & 26.9 & 15.2 & 6.2 & 1.9 & \\
\hline Detritus & 27.1 & 18.8 & 7.2 & 2.0 & \\
\hline All Flows & 26.9 & 15.7 & 6.4 & 1.9 & 0.0 \\
\hline
\end{tabular}

\section{Transfer Efficiencies (Calculated as Geometric Mean for TL II-IV)}

From primary producers: $13.6 \%$

From detritus: $15.4 \%$

Total: $13.9 \%$

\section{Mixed Trophic Impact}

The mixed trophic impact graph (Fig. 2) was used "to assess the effect that changes in the biomass of a group would have on the biomass of the other groups in a system" [20]. Fig. (2) showed the possible, relative direct and indirect impacts that a very small increase of the biomass of the groups to the left would have on the biomass of the groups in the columns, in a steady-state system. The bars pointing upwards indicated positive impacts while those pointing down indicated negative impacts. This was not used for making predictions, primarily because changes in abundance may lead to changes in diet composition, which could not be accommodated with the mixed trophic analysis.

A very small increase in the biomass of the carnivores would have a negative effect on the carnivores, calanoids, cyclopoids and harpacticoids, with the largest effect being seen on the harpacticoids. However, an increase in the biomass of this group would also have a positive effect on the larvaceans, copepodites and the nauplii, with the largest effect being seen on the larvaceans (Fig. 2). A similar increase in the biomass of the calanoids would have a negative effect on all groups with the exception of the carnivores, larvaceans and nauplii. The largest negative impact would be on the larvae (Fig. 2).

If the biomass of the cyclopoids were to increase slightly, it would have small positive impacts on the calanoids, copepodites and larvae. It would have its largest negative impact on the larvaceans (Fig. 2).

An increase in the biomass of the harpacticoids would have no effect on any of the other groups (Fig. 2).

A slight increase in the biomass of the larvaceans also seemed to have very little impact on the remaining groups. It would have a small positive impact on the cyclopoids and

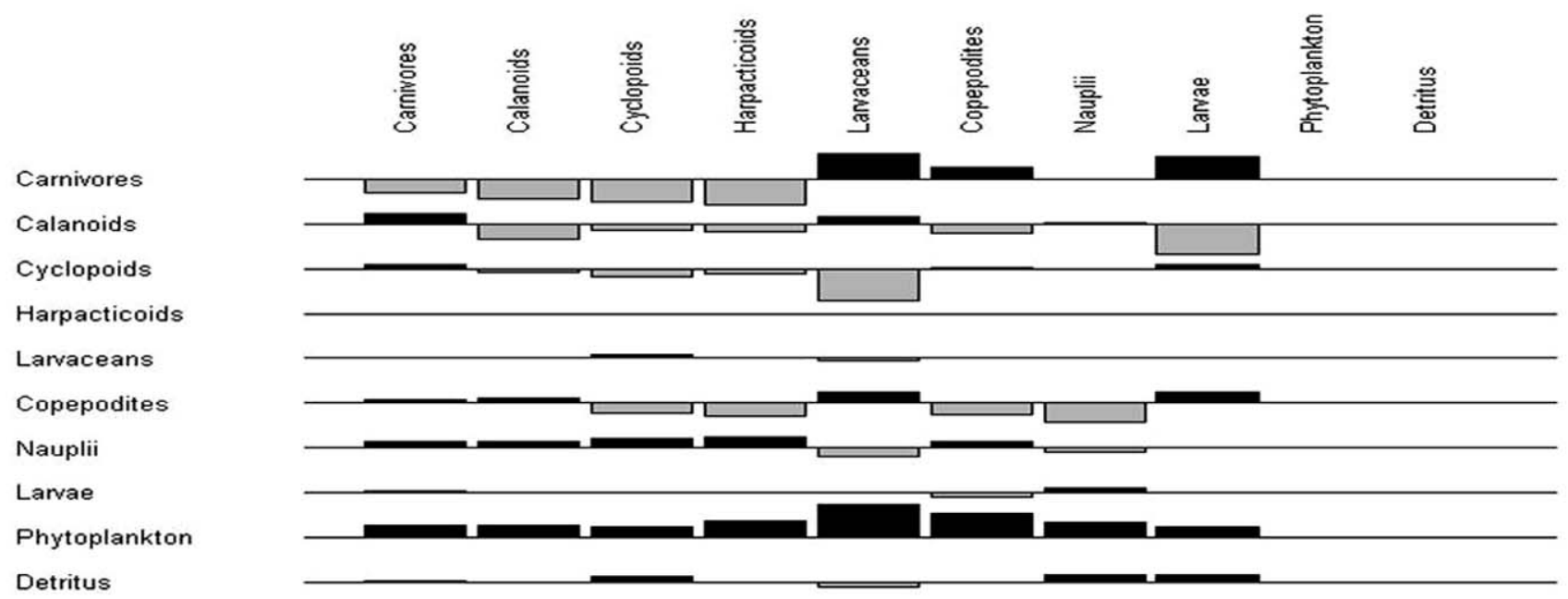

Fig. (2). Mixed trophic impact graph for the Discovery Bay Ecopath model, showing the direct and indirect impact that a very small increase of the biomass of the groups to the left have on the groups above the graph. 
small negative impacts on the harpacticoids and larvaceans (Fig. 2). An increase in the biomass of copepodites affected all the other groups. It had positive impacts on the carnivores, calanoids, larvaceans and larvae. The biomass increase negatively impacted the cyclopids, harpacticoids, copepodites and nauplii (Fig. 2). A small increase in the biomass of the nauplii had positive effects on five groups: the carnivores, calanoids, cyclopoids, harpacticoids and copepodites. It negatively impacted the remaining groups with the largest effect being seen on the larvaceans (Fig. 2). An increase in the biomass of the larvae would also have little effect across the groups. Small positive effects would be seen on the carnivores and nauplii and small negative effects would be seen on the calanoids, copepodites and larvae (Fig. 2). A small increase in the biomass of phytoplankton would have positive effects on all groups, impacting the larvaceans the most and the cyclopoids and larvae the least (Fig. 2). Again, an increase in detrital biomass would have mostly positive effects (but smaller than those seen with increases in phytoplankton biomass), except on the larvaceans (Fig. 2).

\section{Trophic Flows for Discovery Bay}

The flows and biomasses among the plankton groups in Discovery Bay were presented in a single graph (Fig. 3) and the summary of these flows were presented in Table $\mathbf{1 0 .}$

A summary of the parameter values for the mass-balance model were presented in Table $\mathbf{1 0 .}$

\section{Mass-Balance Solution}

The Ecopath programme was required to estimate the biomass of two groups: the nauplii and copepodites. Even though the biomass of these groups had been estimated during the course of this study, mass-balance could not be achieved using these estimates without drastic (unreasonable) adjustments in diet compositions and/or $\mathrm{P} / \mathrm{B}$ ratios. Previous studies [40] have indicated that the abundance (and therefore the biomass) of these groups (particularly the nauplii) are usually underestimated by traditional sampling methods. In fact, a review of the $20 \mu \mathrm{m}$ collections indicated that the nauplii were the dominant microzooplankton group in Discovery Bay. It was therefore assumed that the ecotrophic efficiencies, diet compositions and $\mathrm{P} / \mathrm{B}$ ratios were the more reasonably estimated parameters and Ecopath was asked to estimate the biomass of the nauplii and copepodites in order to achieve massbalance. The Ecopath estimated biomass of the nauplii and copepodites (122365 and $120596.4 \mathrm{~J}$ respectively) was approximately 122 and 55 times higher than the estimates produced by this study (1005 and $2195 \mathrm{~J}$ respectively). This again indicated that the nauplii had been more severely underestimated than the copepodites. Both the nauplii and the copepodites were enumerated from the $64 \mu \mathrm{m}$ collections and it may be that the smaller nauplii (more accurately estimated from a smaller mesh size) play a trophically significant role in Discovery Bay.

\section{Ecotrophic Efficiency Estimates}

\section{DISCUSSION}

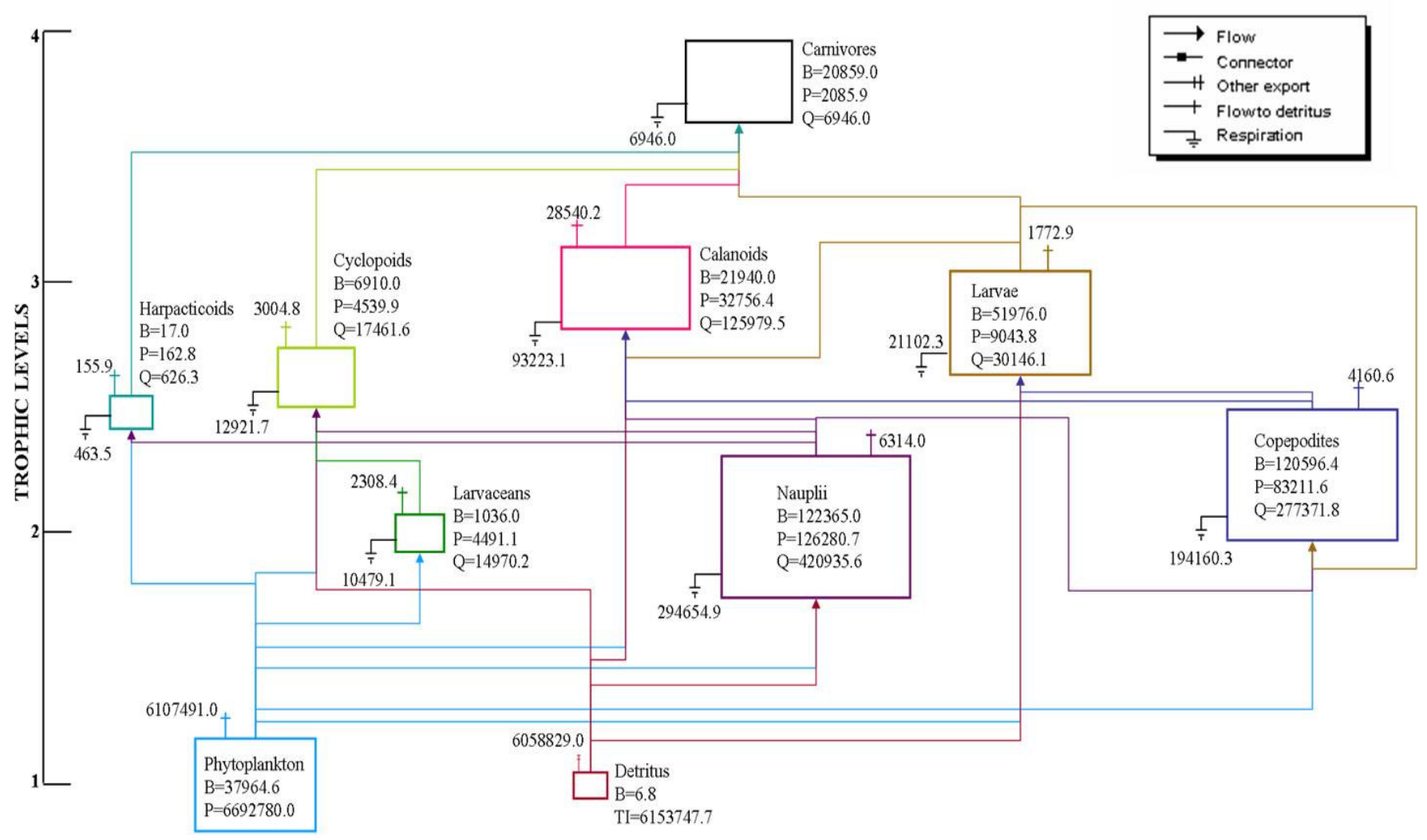

Fig. (3). Flow diagram of plankton groups in Discovery Bay. Flows are expressed in $\mathrm{J} \mathrm{m}^{-2}$ year ${ }^{-1}$. B indicates biomass and $\mathrm{P}$ production. 
Table 10. Summary of Net Flows for Discovery Bay Model Presented in Fig. (3) Above

\begin{tabular}{|l|c|c|}
\hline \multicolumn{1}{|c|}{ Parameter } & Value & Units \\
\hline \hline Sum of all consumption (C) & 894437.1 & $\mathrm{~J} / \mathrm{m}^{2} / \mathrm{year}$ \\
\hline Sum of all exports (EX) & 6058829 & $\mathrm{~J} / \mathrm{m}^{2} / \mathrm{year}$ \\
\hline Sum of all respiratory flows (R) & 633950.9 & $\mathrm{~J} / \mathrm{m}^{2} / \mathrm{year}$ \\
\hline Sum of all flows into detritus (D) & 6153747 & $\mathrm{~J} / \mathrm{m}^{2} / \mathrm{year}$ \\
\hline Total system throughput (T) & 13740963 & $\mathrm{~J} / \mathrm{m}^{2} / \mathrm{year}$ \\
\hline Sum of all production (TP) & 6955352 & $\mathrm{~J} / \mathrm{m}^{2} / \mathrm{year}$ \\
\hline Calculated total primary production (TPP) & 6692780 & $\mathrm{~J} / \mathrm{m}^{2} / \mathrm{year}$ \\
\hline Total primary production/total respiration (TPP/R) & 10.557 & \\
\hline Net system production (NP) & 6058829 & $\mathrm{~J} / \mathrm{m}^{2} / \mathrm{year}$ \\
\hline Total primary production/total biomass (TPP/B) & 17.444 & \\
\hline Total biomass/total throughput (B/T) & 0.028 & $\mathrm{~J}$ \\
\hline Total biomass (excluding detritus) (B) & 383664 & $\mathrm{~J} / \mathrm{m}^{2}$ \\
\hline Connectance Index (CI) & 0.309 & \\
\hline System Omnivory Index (OI) & 0.166 & \\
\hline Overhead & 10.6 & \\
\hline
\end{tabular}

The ecotrophic efficiency of the "carnivores" was of course estimated to be zero as they represented the top-level predators in this model with none of their production being transferred to any other trophic level in the plankton. This, of course, is simply due to the constraints under which the model was constructed: that is, the model was only meant to describe the trophic interaction among the plankton groups in Discovery Bay. An adjustment in this parameter would automatically be made if the model were expanded to include the (planktivorous) fish groups in the bay that would potentially feed on this group or compete with them for resources.

The ecotrophic efficiency of phytoplankton is low (0.087) considering that it is the primary producer being used as a food source by several zooplankton groups. This was due to it high rate of productivity. The largest ecotrophic efficiency was estimated for the larvae probably due to the fact that it was a major constituent of the diet of the calanoids, which was the second largest (non-estimated) zooplankton group in the model. The other relatively large ecotrophic efficiencies were estimated for the larvaceans and the cyclopoids, indicating that the relatively low biomass of these groups is fairly well grazed.

\section{Mixed Trophic Impacts}

This analysis essentially acted as "sensitivity analysis" for the model [20]. For example, the harpacticoids and larvaceans would generally have little impact on the plankton community in Discovery Bay, whereas the phytoplankton appeared to be quite important to all zooplankton groups.

This analysis also illustrated more detailed direct and indirect impacts on all the groups. In most cases, an increase in the biomass of any of the zooplankton groups would ultimately negatively impact that group, due probably to competition over limited resources. Competition for food resources also led to negative impacts when considering the effects that the calanoids had on the cyclopoids and harpacticoids and similarly, the impacts that the cyclopoids had on the calanaoids and harpacticoids.

In some cases, as expected, an increase in predator biomass negatively impacted prey biomass. This was seen in the impacts of the carnivores on the copepod groups, for example. Conversely, increasing the biomass of prey types could also lead to increased predator biomasses due, of course, to increased food resources. For example, positive impacts to the carnivores were noted with increasing calanoid, cyclopoid, copepodite and larval biomass. However, even though the carnivores did not feed directly on nauplii and phytoplankton, these two groups still indirectly (positively) impacted the carnivores due to their effect on carnivore prey types (calanoids, cyclopoids and harpacticoids).

Other indirect impacts were noted especially with respect to the larvaceans. Any decrease in predator biomass (cyclopoids) brought about by interactions with other groups, would positively impact larvacean biomass. For example, increased predation on the cyclopoids by the carnivores would indirectly result in a significant positive increase in larvacean biomass. Conversely, any interaction that allowed for an increase in the biomass of the cyclopoids could ultimately result in a negative impact on the larvaceans. For example, there is no direct relationship between the nauplii and the larvaceans. That is, one group does not feed on the other. However, increasing the biomass of the nauplii, negatively impacted the larvaceans due to its positive impact on the cyclopoids (larvacean predator). However, it is to be noted that the large positive impact that phytoplankton had on the larvaceans outweighed the positive impact that the phytoplankton also had on the cyclopoids-that is, the 
phytoplankton effect was large enough to outweigh any increased predation by the cyclopoids. In fact, a small increase in phytoplankton biomass seemed to be enough, in general, to outweigh the effects of both predation and competition.

\section{Trophic Levels and Trophic Efficiencies}

Trophic (feeding) levels (TL) express the position of an animal in the food web relative to the primary producers (TL =1) [41]. Because most animals feed at different "trophic levels", Ecopath places species on "fractional trophic levels" that reflect the different levels at which they feed [42]. Therefore, "a consumer eating $40 \%$ plants $(\mathrm{TL}=1)$ and $60 \%$ herbivores $(\mathrm{TL}=2)$ would have a trophic level of $1+(0.4 * 1$ $+0.6 * 2)=2.6$ " [42]. Trophic levels for the plankton in Discovery Bay ranged from 1 (primary producers) -3.82 (carnivores) (Table 9). Except for the larvaceans and nauplii which fed exclusively on phytoplankton $(\mathrm{TL}=2)$, these fractional trophic levels reflected the extensive omnivory which is now thought to take place in the zooplankton [3436].

Generally, energy utilization is not very efficient in marine ecosystems. For example, approximately $1 \%$ of the available solar energy is utilized by phytoplankton for the production of organic matter. In addition to this, $70-90 \%$ of this stored energy is used up by them, leaving $10-30 \%$ (transfer efficiency) available to the next trophic level. Similarly, most of the energy available from the food eaten by consumers, (again 70-90\%), is used by them. The transfer efficiencies (overall 13.9\%), calculated by Ecopath for this model, clearly fall within the expected range.

\section{Summary Statistics}

Christensen and Pauly, [42, 43] described how a selection of Odum's [44] twenty-four attributes of ecosystem maturity, could be applied to trophic mass-balanced models in order to describe the developmental stage of an ecosystem. According to the summary statistics calculated by Ecopath for Discovery Bay (Table 10), this ecosystem (with respect to the plankton groups) is one which is still in the developmental stages and has yet to reach maturity.

As indicated in Table 9, the ratio between total primary production and respiration (TPP/R) was used as an index of the relative maturity of an ecosystem, such that the ratio would approach 1 as the systems mature [44]. Forty-one aquatic ecosystems were compared and it was found that the majority of the TPP/R ratios ranged from $0.8-3.2$, with extreme values $<0.8$ and $>6.4$ [15]. The TPP/R ratio of the plankton community in Discovery Bay was, at 10.55, considered extremely high and indicative of a developing ecosystem (Table 10).

There were a number of factors which could have led to high TPP/R ratio estimated for Discovery Bay including the omission of bacterial activity from the model [24]. Bacterial activity was not considered during the construction of this model due mainly to the lack of reliable information which could be used to assess the flows associated with this community [20]. This would lead to an underestimation of " $R$ " and a subsequent overestimation of TPP/R. Also, it is to be expected that the respiratory rates of plankton are lower than that of fish, birds and mammals. Therefore, comparing the $\mathrm{TPP} / \mathrm{R}$ ratio of this (plankton) ecosystem to those previously reviewed [24], may be somewhat misleading as the estimated respiratory flows for a model of a plankton community would likely to be much lower than that estimated for models which include fish, bird and mammalian functional groups. This would again result in comparatively higher TPP/R ratios for the plankton models.

The Gross production/Biomass (TPP/B in Table 10) ratios of the forty-one reviewed ecosystems were also ranked according to the maturity ranking suggested by Odum [44] [24]: that is, it is high in developing systems and low in mature systems. A NP/B ratio of 17.44 (Table 10), again suggests a fairly immature system that is still developing.

Another indicator of a system's maturity, the Finn Index [45] was incorporated into the Ecopath II software [43]. The Finn Index [45] was developed to quantify one of Odum's [44] properties of system maturity, that is, the percentage of all fluxes generated by recycling. Originally, Odum suggested, that recycling increases as a system matures. Finn's index could therefore be applied to gauge the health and maturity of ecosystems [46]. However, it has been suggested [46] that this may not be as simple a relationship as originally suggested. While Wulff and Ulanowicz [47] suggested that the opposite may be the case (that is, recycling decreases as a system matures), Vasconcellos et al., [48] concluded that "systems with higher capacity to recycle detritus are systems with a higher ability to recover from perturbations". This study concluded that "the results are in agreement with E.P. Odum's theory of ecosystem development, where recycling is interpreted as a chief positive feedback mechanism that contributes to stability in the mature systems by preventing overshoots and destructive oscillations due to external impacts". Therefore, if we were to apply the original terms to the Finn's index calculated for Discovery Bay (minimal) (Table 10), then it is clear that this was still a developing ecosystem with open mineral cycles and poor nutrient conservation, similar (in this respect) to the ecosystem of the Broa Reservoir in São Paulo State, Brazil [5].

This model presented in this paper represented the "best fit" for the data that was collected during the course of this study. The most obvious question raised by this model arose from the need to allow the model to estimate the biomass for the copepodites and nauplii in order to achieve mass-balance, strongly suggesting the need for more accurate estimates for the densities of these groups. One possibility includes generating a model with naupliar data generated from the $20 \mu \mathrm{m}$ collections to see if this mesh size more accurately captures the size range of nauplii in the bay.

\section{REFERENCES}

[1] Polovina JJ, Ow MD. ECOPATH: a user's manual and program listings. Southwest Fish Cent Adm Rep 1983; H82-23: 46.

[2] Polovina JJ. An overview of the ECOPATH model. Fishbyte 1984; 2(2): 5-7.

[3] Opitz S. Trophic interactions in Caribbean coral reefs. ICLARM Tech Rep 1996; 43: 341.

[4] Christensen V. A model of trophic interactions in the North Sea in 1981, the Year of the Stomach. Dana 1995; 11(1): 1-28.

[5] Angelini R, Petrere M Jr. The ecosystem of Broa Reservoir, Sao Paulo State, Brazil, as described using ECOPATH. NAGA 1993; 19(2): 36-41. 
[6] Arias-González JE, Delesalle B, Salvat B, Galzin R. Trophic functioning of the Tiahura reef sector, Moorea Island, French Polynesia. C Reefs 1997; 16: 231-46.

[7] Venier JM, Pauly D. Trophic dynamics of a Florida keys coral reef ecosystem. Proc. $8^{\text {th }}$ Coral Reef Sym 1997; 1: 915-20.

[8] Guénette S, Morato T. The Azores Archipelago, 1997. In: Guénette S, Christensen V, Pauly D, Eds. Fisheries impacts on North Atlantic Ecosystems: Models and analyses. Vancouver, BC, Canada: Fisheries Centre, University of British Columbia, 2001; vol. 9(4): pp. 241-270.

[9] Allain V. A preliminary Ecopath model of the pelagic ecosystem of Western and Central Pacific Ocean. EB WP-10. WCPFC First Scientific Committee. Noumséa, New Caledonia. 8-19 August 2005.

[10] Mohamed KS, Zacharia KU, Muthiah C, Abdurahiman KP, Nayak TH. A trophic model of the Arabian Sea Ecosystem off Kamataka and simulation of fishery yields for its multigear marine fisheries. CMFRI publ 2005; 1-83. www.ecopath.orgpublications. Accessed August 2006.

[11] O'Callaghan PA, Woodley JD, Aiken KA, Haughton MO. Marine park development in Jamaica. Report to the OAS tourism development plurinational project, Montego Bay, Jamaica 1998; p. 205.

[12] Google Images. www.google.com.jm/imghp?hl=en\&tab=wi Accessed July, 2009.

[13] UNESCO Monographs on oceanic methodology: Zooplankton sampling. UNESCO, Paris 1968; p. 174.

[14] Van Guelphen L, Markle DF, Duggan DJ. An evaluation of the accuracy, precision and speed of several zooplankton subsampling techniques. J Cons Perm Int Explor Mer 1982; 40: 226-36.

[15] Owre, HB, Foyo M. Copepods of the Florida Current. Fauna Caribea (University of Miami) 1971; pp. 1-137.

[16] Mayer AG, Medusae of the world 1-3. Carnegie Foundation, Washington D.C 1910.

[17] Webber MK. Annual structure and production of the copepod community in a tropical oceanic area. Ph.D Thesis, University of the West Indies (Mona), 1993.

[18] Persad G. Annual abundance, biomass and production of the dominant gelatinous, carnivorous zooplankton (Cnidaria and Ctenophora), off Kingston, Jamaica. M.Phil Thesis, University of the West Indies (Mona), 1997.

[19] Clarke C. The annual cycle of neritic metazooplankton off Kingston, Jamaica with estimates of their annual productivity. M.Sc Thesis, University of Guelph 1988.

[20] Christensen V, Walters CJ, Pauly D. Ecopath with Ecosim: a user's guide. Canada: Publishers: Fisheries Centre, University of British Colombia, Vancouver 2005; p. 154.

[21] Persad G. Trophic interactions among zooplankton in Discovery Bay, Jamaica. Ph.D Thesis, University of the West Indies (Mona), 2007.

[22] Webber MK, Edwards-Myers E, Campbell C, Webber D. Phytoplankton and zooplankton as indicators of water quality in Discovery Bay, Jamaica. Hydrobiologia 2005; 545: 177-93.

[23] Platt T, Irwin B. Caloric content of phytoplankton. ASLO 1973; 18(2): 306-9.

[24] Christensen V, Pauly D. Trophic models of aquatic ecosystems. Conference Proceedings 26. Manila, Philippines: ICLARM 1993; p. 390.

[25] Allen RR. Relationship between production and biomass. J Fish Res Board Can 1971; 28: 1573-81.

[26] Ikeda T, Motoda S. Estimated zooplankton production and their ammonia excretion in the Kuroshio and adjacent seas. Fish Bull 1978; 76: 357-66.

[27] Straile D. Gross growth efficiencies of protozoan and metazoan zooplankton and their dependence on food concentration, predatorprey weight ratio and taxonomic group. Limnol Oceanogr 1997; 42(6): $1375-85$.
[28] Manickchand-Heileman S, Soto LA, Escobar E. A preliminary trophic model of the continental shelf, South-Western Gulf of Mexico. Estuar Coast Shelf Sci 1998; 46: 885-99.

[29] Garces LR, Man A, Ahmad AT, Mohamed-Norizam M, Silvestre GT. A trophic model of the coastal fisheries ecosystem off the West Coast of Sabah and Sarawak, Malaysia. In: Silvestre G, Graces L, Stobutzki I, et al., Eds. Assessment, Management and Fsuture Directions for Coastal Fisheries in Asian Countries. World Fish Center Conference Proceedings. Malaysia: Penang 2003; vol. 67: p. 1120.

[30] Walters C, Martell SJD, Mahmoudi B. An Ecosim model for exploring ecosystem management options for the Gulf of Mexico: implications of including multistanza life history models for policy predications. Bull Mar Sci 2008; 83(1): 251-71.

[31] Madin G, Klein-MacPhee L, Sullivan B, et al. Distribution, abundance and feeding biology of invertebrate predators. Globec Reports 1995 found at http://globec.whoi.edu/globec-dir/reports/ siworkshop.1995/ Accessed June, 2006.

[32] Mills CE. Medusae, siphonophores and ctenophores as planktivorous predators in changing global ecosystems. ICES J Mar Sci 1995: 52: 575-81.

[33] Baier CT, Purcell JE. Trophic interactions of chaetognaths, larval fish and zooplankton in the South Atlantic Bight. MEPS 1997; 146: 43-53.

[34] Turner JT. The feeding ecology of some zooplankters that are important prey items of larval fish. NOAA Technical Report NMFS 1984; 7: 28.

[35] Turner JT. The importance of small planktonic copepods and their roles in pelagic marine food webs. Zool Stud 2004; 43(2): 255-66.

[36] Turner JT. Zooplankton feeding ecology: contents of fecal pellets of the cyclopoid copepods Oncaea venusta, Corycaeus amazonicus, Oithona plumifera, and O. simplex from the Northern Gulf of Mexico. In Paul Parey Scientific Publishers (publ.) Mar Ecol 1986; 7(4): 289-302.

[37] Hansen BW. Cohort growth of planktotrophic polychaete larvaeare they food limited? MEPS 1999; 178: 109-19.

[38] Okey TA, Pauly D, Eds. Trophic mass-balance model of Alaska's Prince William Sound ecosystem for the post-spill period 19941996. $2^{\text {nd }}$ ed. Vancouver, B.C., Canada: The Fisheries Centre, University of British Columbia 1998; p. 144.

[39] Hopcroft RR. Size-related patterns in growth and production of tropical, marine planktonic communities along a tropical gradient. Ph.D Thesis. University of Guelph 1997.

[40] Roff JC, Turner JT, Webber MK, Hopcroft RR. Bacterivory by tropical copepod nauplii: extent and possible significance. Aquatic Microbial Ecol 1995; 9: 165-75.

[41] Pauly D. The marine trophic index. The Sea Around Us Project Newsletter. Issue 29, May/June 2005.

[42] Christensen V, Pauly D. ECOPATH II - a software for balancing steady-state ecosystem models and calculating network characteristics. Ecol Model 1992; 61: 169-85.

[43] Christensen V, Pauly D. Changes in models of aquatic ecosystems approaching carrying capacity. Ecol Appl 1998; 8(1 Suppl): S104S109.

[44] Odum EP. The strategy of ecosystem development. Science 1969; 164: $262-70$.

[45] Finn JT. Measures of ecosystem structure and function derived from analysis of flows. J Theor Biol 1976; 56: 363-80.

[46] Allesina S, Ulanowicz RE. Cycling in ecological networks: Finn's index revisited. Comput Biol Chem 2004; 28: 227-33.

[47] Wulff F, Ulanowicz RE. A comparative anatomy of the Baltic Sea and Chesapeake Bay ecosystems. In: Wulff F, Field JG, Mann KH, Eds. Network analysis in Marine Ecology - Methods and Applications. Coast Estuar Studies. New York: Springer-Verlag 1989; vol. 32: pp. 232-56.

[48] Vasconcellos M, Mackinson S, Sloman K, Pauly D. The stability of trophic mass-balance models of marine ecosystems: a comapartive analysis. Ecol Model 1997; 100: 125-34. 